\title{
Clinical Relapse of Multiple Myeloma or Plasma Cell Leukemia by IMWG
}

National Cancer Institute

\section{Source}

National Cancer Institute. Clinical Relapse of Multiple Myeloma or Plasma Cell Leukemia

by IMWG. NCI Thesaurus. Code C123908.

Relapse of multiple myeloma or plasma cell leukemia is defined as follows: Development of new soft tissue plasmacytomas or bone lesions; Definite increase in the size of existing plasmacytomas or bone lesions. A definite increase is defined as a 50\% (and at least $1 \mathrm{~cm}$ ) increase as measured serially by the sum of the products of the crossdiameters of the measurable lesion; Hypercalcemia (> $11.5 \mathrm{mg} / \mathrm{dL}$ ) $[2.65 \mathrm{mmol} / \mathrm{L}]$; Decrease in hemoglobin of $>2 \mathrm{~g} / \mathrm{dL}[1.25 \mathrm{mmol} / \mathrm{L}]$; and rise in serum creatinine by 2 mg/dL or more [177 mmol/L or more]. (International Myeloma Working Group (IMWG) Uniform Response Criteria for Multiple Myeloma. ) 